\title{
The Fight over Danish Nature: Explaining Policy Network Change and Policy Change
}

\section{Anders Branth Pedersen}

This is the manuscript originally submitted for publication in Public Administration, and updated to include any amendments made after peer review.

Please cite this publication as:

Pedersen, A.B., 2010, 'The Fight over Danish Nature: Explaining Policy Network Change and Policy Change'. Public Administration 88:2, pp.346-63.

The definitive version is available at www.blackwell-synergy.com'

Link to definitive version: http://onlinelibrary.wiley.com/doi/10.1111/j.14679299.2009.01790.x/abstract

Corresponding author: $\underline{\text { abp @envs.au.dk }}$

I am grateful to Blackwell Publishing and Public Administration for giving me the possibility to share this accepted manuscript version of the article.

This is the peer reviewed version of the following article: [Pedersen, A.B., 2010, 'The Fight over Danish Nature: Explaining Policy Network Change and Policy Change'. Public Administration 88:2, pp.346-63.], which has been published in final form at [https://doi.org/10.1111/j.1467-9299.2009.01790.x]. This article may be used for non-commercial purposes in accordance with Wiley Terms and Conditions for Use of Self-Archived Versions. 


\begin{abstract}
The policy network approach is widely recognized for the ability to describe different networks. Adding the concepts of 'policy image' and 'line of conflict in the party system' makes it possible to explain policy network change and policy change too. This argument is supported by a comparison of the 1960 decision to straighten Denmark's largest river, the Skjern River, to gain farmland, and the 1987 decision to restore the river and recreate the wild nature of the river valley. The fight over Danish nature has historically been a fight between a land reclamation network and a nature protection network - two networks trying to promote different policy images. Coupled with a line of conflict in the party system, new policy images connected to the Skjern River decisions led to radical policy changes.
\end{abstract}

\title{
1. Introduction
}

Denmark ranks among the world's most cultivated countries. Today, 63 pct of the land area of Denmark is registered as cultivated and only 9 pct as 'nature' (Hansen 2003: 36, 313). The widespread cultivation is partly due to the numerous land reclamation projects implemented in the period 1750-1970. Rivers were straightened out and lakes, moors and fjords drained, with the aim of claiming fertile farmland. At the end of the 1960s, however, the Danish land reclamation policy came to a halt. No new projects were being implemented - on the other hand, no farmland was being returned to nature. This phase lasted until the mid-1980s when a new policy came into place. The state started to finance a number of nature restoration projects, giving reclaimed land back to nature, thus representing a change in the policy framework. What has led to this u-turn in rural policy in Denmark with regard to land-use in the wider countryside?

A characteristic of the policy process described above is that interest groups have exercised a striking influence on the decisions involved, making it relevant to analyse the policy process within a policy network framework (Marsh \& Rhodes 1992). The policy 
network approach is generally recognized for its descriptive qualities in periods with policy stability, but the approach's ability to explain the dynamic elements of networks' origin, change and outcome has been questioned (e.g. Dowding 1995, 2001). Marsh \& Rhodes (1992: 260-61) were aware of the problem and recommended coupling the policy network concept with micro and macro theory.

It is argued that adding the concepts of 'policy image' and 'line of conflict in the party system' to a policy network framework makes it possible to breathe new life into the policy network concept, while networks' coupling of the two concepts makes it possible to explain policy change (Baumgartner \& Jones 1993; Green-Pedersen 2007; see also Jordan 1998; Richardson 2000).

\section{Policy networks and policy images}

In explaining the historically radical policy change outlined above, the British policy network approach is useful, since the network concept in this approach is essentially a comparative concept. The approach addresses the policy consequences of different organizational arrangements and argues that different sectoral policy network types can be linked with differences in sectoral policies - policy networks influence policy outcome (Marsh \& Rhodes 1992; Daugbjerg 1998). Therefore, it is expected that the approach can be applied in an analysis of Danish rural policy, where two different subsector networks are observable through recent history - a nature protection network fighting a land reclamation network. The metaphor of a network focuses on the pattern of formal and informal contacts between government and interest groups, where the involved actors (politicians, public servants, ministries, municipalities, interest organizations, etc.) exert influence on the policy agenda and the decision-making processes.

Comparing different networks demands a network typology. Marsh \& Rhodes (1992) developed a network continuum based on the degree of integration exhibited by the individual network. At one end of the continuum, the weak 'issue networks' are situated and, at the other end, we find the strong 'policy communities'. The policy community describes a tight and 
closed network with a very limited number of members and restricted membership (see e.g. Marsh \& Rhodes 1992; Daugbjerg 1998). All actors in the network are in possession of valuable resources (expertise, money etc.) and there is resource interdependence among the actors - no single actor possesses sufficient material or cognitive resources to solve complex policy problems alone. Integration is high, while there is frequent interaction in this type of network, where the actors are bargaining. Finally, policy communities are highly institutionalized due to a widespread consensus regarding policy principles and procedures to approach policy problems. In contrast, the weak issue network is relatively open, containing many members who disagree on policy principles and procedures to approach policy problems. Here, the pattern of interaction is unstable and based on consultation instead of negotiation.

A strong network will exercise structural power. Policy communities create power relations which privilege the actors organized in the network. Rules, procedures and beliefs support the interests of the actors in the powerful network without the network having to control the political agenda on every occasion. In contrast, an issue network possesses no structural power in itself and the actors in the network will have to rely on possible, individual, non-structural power (resources) to make an impact on the policy (Smith 1990; Daugbjerg 1998).

As mentioned, the network approach's ability to explain the dynamic elements of a network's origin, change, and outcome has been questioned. Marsh \& Rhodes (1992: 257-59) identified four broad categories of exogenous factors influencing policy networks: socioeconomy, government ideology, knowledge, and new institutions (e.g. EC institutions). For instance, regarding land reclamation and nature protection networks, it can be expected that if unemployment figures are very high, it can be difficult for the nature protection network to launch an idea which involves limiting job creation via land reclamation projects. Economic changes are a source of instability in networks (Marsh \& Rhodes 1992: 257). Furthermore, the ideology of the governing party/parties, development of new knowledge (regarding land reclamation/nature restoration), or introduction of new administrative/political 
entities (in environmental and agricultural politics) can influence policy networks' constraints and opportunities. Marsh (1998: 187-88) later acknowledged that 'presence of other networks' and 'public opinion' constitute additional important aspects in the exogenous context. For instance, introduction of a new competing (strong) network will limit the opportunities for network(s) in a specific sector, and so will, for instance, public opinion on environmental matters.

These six exogenous factors influence land reclamation and nature protection networks by providing constraints and opportunities, and changes in this context can, potentially, through the network actors, lead to policy change. It can be added that network actors from time to time will be able to influence the networks exogenous context, for instance by influencing public opinion, but the relationship is more pointing in the other direction - from the context towards the network. Actors in a network calculate strategically, but the network of which they are part provides some constraints and opportunities with regard to maneuvering.

It is argued in this article that actors in a policy network can strengthen the network's integration, endogenously, by developing a supporting policy image (Baumgartner \& Jones 1993) when there are major changes in the exogenous context surrounding the networks. Changes in the exogenous context can result in network changes by altering some network actors' perception of reality such that it diverges markedly from the appreciative system of the network (Smith 1993; Smith 2000: 98); or by changing network actors' perception of the relative bargaining power. A changing exogenous context can cause changes in the bargaining power of the networks involved (Blom-Hansen 1997: 686), e.g. by changing the value of different actor resources (Smith 1993; Smith 2000). In other words, the perception of policy constraints and opportunities held by the central actors changes. It can be argued that a new perception can lead the actors of the network to build up, and communicate, a new policy image (or strengthen an existing image), thereby developing greater consensus among the network actors regarding policy principles and procedures to approach policy problems, with the aim of gaining more structural/bargaining power. Furthermore, a new image may attract 
strong actors to the network (Baumgartner \& Jones 1993: 8-9). Greater consensus will improve the institutionalization of the network (see Daugbjerg 1998), which in turn will strengthen the network and make it move more towards the policy community pole. The line of argument pursued here might help to solve the problem of the institutionalization dimension of policy networks being an underdeveloped area of research (Atkinson \& Coleman 1992). Furthermore, consensus on policy principles and procedures can increase the integration of the policy network, because the actors here have reached a position where there is a common understanding on principles and procedures in their communication, and this can increase the frequency with which they meet. In this way, a changing context can be transformed by the network actors into a strengthening of the policy network. As a bonus, a new policy image/idea can have a virus-like, disintegrating effect on an old (competing) policy community (Richardson 2000: 1021).

Policy image can be explained as 'how a policy is understood and discussed' (Baumgartner \& Jones 1993: 25-26). Specialists are more familiar with an issue than others and they are, from time to time, able to explain an issue in simplified and favourable terms to non-specialists. The dynamic (and the stability) in Baumgartner \& Jones' punctuated equilibrium model is traceable to the agenda-setting process where actors attempt coupling policy image and policy venue. Policy venues are groups or institutions in a society that have the authority to make decisions (ibid: 31 ). Image and venue can combine to produce rapid policy change, or they can interact to reinforce the current assignment of authority (ibid: 38).

The punctuated equilibrium model does not have a clearly stated differentiated network/monopoly concept, and this makes it impossible to rank different policy monopolies according to their strength. 'Policy monopolies' possess two important characteristics. 'First, a definable institutional structure is responsible for policymaking, and that structure limits access to the policy process. Second, a powerful supporting idea is associated with the institution' (Baumgartner \& Jones 1993: 7). Policy monopolies appear to be quite similar to policy communities; a monopoly surrounding the framing of a concept will also be apparent in a very strong policy community. But if it is impossible to identify different types of 
networks/monopolies it becomes difficult to analyse network change; the problem is solved in this article by coupling the concept of 'policy image' with the policy network approach.

Furthermore, Green-Pedersen (2007) has argued that whether or not an issue becomes political in a European context depends on the extent to which the issue can be attached, not to a policy venue - policy venues are very few in European parliamentary systems compared to Baumgartner \& Jones' US context - but instead to an existing line of conflict in the party system. For instance, in many countries the environment has become a line of conflict. Consequently, if an issue can be attached to 'environmental problems', chances of politicizing the issue are high, making policy change possible. Therefore, a new policy image developed by the policy network can both strengthen the policy network, and, coupled with a line of conflict, lead to policy changes. In this article, the basic dynamic of Baumgartner \& Jones' model is kept, but 'policy venue' is replaced with 'line of conflict' to fit the model to a European context, and 'policy monopoly' is replaced with 'policy network', to make it possible to distinguish between different types of networks.

The analysis of the fight over Danish nature touches upon three dialectical relationships between: a) The structure of the network and the participants, b) The network and the context, c) The network and the outcome (Marsh \& Smith 2000; Toke \& Marsh 2003).

\section{Method and data}

One approach when analysing policy networks is to map who participates in the sectoral decision-making process and then classify this as one (large) network. Another, more uncommon, but in this case more promising approach, is, based on the same actors, to identify two conflicting networks in the same sector (Daugbjerg \& Pedersen 2004: 222; Bulkeley 2000). The paper applies the latter approach, identifying two subsector networks $-\mathrm{a}$ land reclamation network and a nature protection network in conflict over rural policy regarding land-use in the wider countryside - an approach which paves the way for a more dynamic analysis, and makes it easier to observe network changes. 
The comparative analysis is based upon two detailed case studies of the Skjern River - the decision to straighten Denmark's largest river (by volume) in the 1960s and the decision to restore the river in the 1990s, focusing on the policy networks involved. The two Skjerncases can be regarded as extreme cases (e.g. Flyvbjerg 2003: 150) because, it is argued, the decisions are, in contrast to other 'river cases', important for development of new policy images, which is unusual for Danish nature restoration and land reclamation projects. The decision-making processes and the development of new policy images are analysed qualitatively through consultation of a considerable number of different data sources: hitherto unpublished archive records (minutes, letters, reports, etc.) regarding land reclamation and nature restoration from the four most important actors (the Society for Nature Conservation, the Heath Society, the Land Reclamation Board, and the Ministry of Environment) in the two policy networks, a number of articles from both local and national newspapers (for instance based on keyword searches in newspaper databases going back to 1945), a TV programme, two in-depth interviews, as well as a variety of further documents. The multitude of data sources increases the chances of performing a valid analysis (Yin 1994: 80).

The economic part of the exogenous context is analysed through unemployment statistics and the economic importance of the agricultural sector. Changes in government ideology are analyzed in accordance with colour of government. New knowledge will be understood as new knowledge on land reclamation or nature restoration. New institutions will be analysed as new (or the termination of old) administrative entities in agricultural and environmental politics. Presence of other networks will be analysed by detecting whether new networks have been introduced. Finally, public opinion will be analysed through data on public opinion towards environmental matters in general.

The development in the extent to which the environment in general is discussed in the Danish parliament operationalizes the factor 'line of conflict in the party system'. GreenPedersen (2006) has made a calculation of this for the entire period 1953-2002 based on a database containing all Danish parliamentary bills and resolutions, interpellation debates, accounts, and questions to the minister from 1953 to 2003; altogether, 82,537 activities. 


\section{The land reclamation network}

As an agricultural country, Denmark has a long tradition of straightening rivers and draining lakes, moors and fjords, for the purpose of increasing available farmland. The primary inspiration for these projects came from the UK during the 18th and 19th century, but it is likely that Denmark was also influenced by Dutch and Prussian land reclamation projects (Pedersen 2006: 67; Blackbourn 2006). In particular, after the Danish defeat in the second Schleswig War (1864), where Southern Jutland was lost to Prussia and Austria, land reclamation was systematized as a way of winning back lost territory and, needless to say, as a way of earning income for those involved in the projects. The establishment of a private foundation, the Danish Heath Society, by a group of influential men in 1866 created a policy entrepreneur committed to land reclamation on heathland areas. Later, when the engineers of the heath society had cultivated most of the heaths, the company moved on to new tasks in dewatering meadowland, draining lakes and moors, straightening rivers, etc. A parallel can be drawn to Maass' (1951) famous description of the US army engineers and the exploitation of the rivers of North America.

From early on, there was close interaction between the interest organizations and the government, and interaction was further improved when a Ministry of Agriculture was established in 1896 in response to the wishes of an agricultural organization (Hertz 1996). A strong land reclamation policy community was born consisting of a few core actors: the Heath Society, the Ministry and the agricultural organizations. Furthermore, there were strong bonds to the Danish Parliament, where both the Heath Society and the agricultural organizations were represented by politicians who were also members of the interest organizations (Hertz 1996; Geckler 1982). There was resource interdependency among the actors: The Heath Society had a great deal of expertise and a comprehensive organizational capacity (supported by state grants); the Ministry also possessed expertise and could secure the legitimacy of the land reclamation projects as well as allocate finances; the agricultural organizations were in possession of economic resources and represented a large number of plot owners (and voters). 
The degree of network integration further increased when the ministry and the agricultural organizations were offered seats on the board of the Heath Society in 1921 (three seats for the ministry, two for the organizations), and meeting frequency therefore increased. Finally, there existed a consensus among these actors regarding policy principles and procedures to approach policy problems - the goal was to provide as much farmland as possible, supported by state grants (Pedersen 2006).

In response to a suggestion from the Heath Company, from 1933 onwards farmers were entitled to a 50 pct. state grant when improving waterlogged farmland, as a measure to promote employment (Geckler 1982: 99; Hansen 2003: 23). In 1940, following the German occupation of Denmark, the Council of Unemployment asked the Heath Society for new measures to promote employment. The result was an act on the reclamation of land (Rigsdagstidende 1940/41). According to the act, landowners were entitled to a state grant of two thirds of the costs of establishment, when implementing new land reclamation projects (draining of fjords, lakes, river valleys, etc). Another purpose of the act was to promote the production of grain and feed. The period 1940-70 became a 'golden period' for the land reclamation network.

The act on land reclamation institutionalized the land reclamation network even further by adding a new actor to the network (Baumgartner \& Jones 1993). A Land Reclamation Board, the purpose of which was to recommend projects to the Ministry of Agriculture upon request from the landowners, was established. The frequent meetings of the board - there were normally several meetings each month (archive files of the Land Reclamation Board) - represented the pivotal point for the very powerful policy community. Members were the Permanent Under-Secretary of the Ministry of Agriculture, one representative from the Heath Society, one from the union of engineers (this representative was a former employee of the Heath Society (Kraks Blaa Bog)), two farmers (these two farmers were also members of the Danish Parliament) and one representative from each of the Ministries of Public Works, Finance, and Labour. In 1953, a representative from the Ministry of Fisheries was added. No actors representing environmental interests were members of the 
committee. Agricultural organizations were not directly represented either, but they were indirectly represented by the Heath Society - as mentioned, agricultural organizations held seats on the board of the society.

The chairman of the Land Reclamation Board stated at the board's first meeting in November 1940 that the official purpose to combat unemployment, stated in the act, was 'almost to be considered as a fanfare'. The board was, according to the chairman, not obliged to do the utmost to deliver employment to unemployed, because the workers had to be suitable for the job (archive files of the Land Reclamation Board). Implicit in this is that the purpose of improving production was given first priority by the policy community, despite the fact, that the act was enacted with the purpose of fighting unemployment. The chairman was the Permanent Under-secretary of the Ministry of Agriculture and he was also a member of the board of the Heath Society (Kraks Blaa Bog).

The new act accelerated the number of projects dramatically. In the period 19401970, approximately 4 pct of the Danish territory was dewatered under the act on land reclamation (Landbokommissionen 1966). On average, one project a week was approved by the board during the 30 year period (archive files of the Land Reclamation Board). Unfortunately, most of the projects concerned areas of natural interest which were appreciated by a nature protection network.

\section{The nature protection network}

The nature protection network, in contrast, was loosely integrated. Nature interests had, following a trend in Europe and US, been organized in the Danish Society for Nature Conservation since 1911 (Madsen 1979:22-25). The organization was allowed to submit statements on land reclamation projects, but in practice had very limited power (Pedersen 2004).

Furthermore, a Council on Nature Conservation was established when an act on nature conservation was implemented in 1917. The five members of the council were natural scientists and were consulted in business relating to nature conservation projects. However, 
the chairman of the council in the period 1925-44 came from a leading position in the Danish Heath Society, where he e.g. led the works on draining the Danish moors, and for many years, the scientists in the council often publicly disagreed with the Danish Society for Nature Conservation regarding questions of nature conservation (Madsen 1979).

In addition, the Danish Ornithological Society, professional fishermen's organizations, angling organizations, the Danish Outdoor Council and the Ministry of Fisheries all had some interest in putting an end to the land reclamation projects, and these actors can be considered members of the nature protection network along with the Society for Nature Conservation and the Council on Nature Conservation. However, these actors were not in possession of significant resources (although the Ministry of Fisheries did have a seat on the Land Reclamation Board from 1953). Moreover, the actors in the nature protection network had a much more infrequent, unstable and unorganized pattern of contact than the actors in the land reclamation network (Pedersen 2006), and they were not in total agreement as regards the ultimate purpose of fighting land reclamation projects; some wanted recreational areas with beautiful scenery, some wanted more fish, etc. Also, it was not until 1971 that a Ministry of the Environment was established. Before that, nature protection was under the jurisdiction of shifting ministries (Justice, Culture, and Prime Minister's department), which at the same time were focusing on a lot of other political questions other than nature protection. The network, in itself, possessed almost no structural power and was subordinate to the structural power of the land reclamation network.

\section{The decision to straighten the Skjern River}

The decision to straighten the Skjern River and drain the river valley demonstrates the power of the land reclamation network. The idea of straightening Denmark's largest river and drain 4,000 hectare of river valley to improve conditions for cornfields gained ground when the act on land reclamation was passed in 1940. Local agricultural organizations appointed a committee to win the Skjern River landowners over to the project. Initially, convincing landowners in relation to the prospect of draining the river valley was problematic. Even 
though the land owners only were engaged to pay one third of the costs, they feared, that the project would not be profitable for them. But, when the Heath Society presented a project in 1955, out of 834 landowners, 360 voted for a Skjern River project and 111 against, resulting in the project being agreed upon (315 landowners did not show up at the meeting) (Pedersen 2004). In practice, the project came to be considered and recommended by the Land Reclamation Board's sub-committee for Jutland. The sub-committee consisted of three members, all having a direct connection with the Heath Society (ibid). The members were: 1 ) the manager of the Heath Society, 2) a member of the Danish Parliament (Liberal Party), a farmer himself, representing the farmers in the committee and, furthermore, a former member of the board of representatives in the Heath Society, 3) a former employee of the Heath Society. It was not surprising, therefore, that the committee recommended the Heath Society's project proposal without objection.

The huge project was controversial. But when the Society for Nature Conservation in 1955 was asked for a statement, the answer given was ambivalent. The organization's experts responded that from a freshwater biological viewpoint there were no sufficiently strong arguments for opposing the project, although the project's predicted negative impacts on birdlife were regretted. However, from internal communications in the organization, and the organizations communication with other members of the network, it is evident that e.g. the executive committee regretted the loss of scenic beauty, but that in view of the expected economic benefits for the country in a period of recession and high unemployment, the organization, and other actors of the network, found it difficult to protest (Pedersen 2004; archive-files of the Society for Nature Conservation). It can be added that severe ochre pollution in straightened Danish watercourses was described as early as 1947 (Larsen \& Olsen 1947). According to Baumgartner \& Jones (1993:20), important political questions are often ignored for years. The knowledge existed, but was not spread to the public.

In the late 1950s there were some protests from local fishermen and a negative attitude among a number of plot owners, but the opposition did not gain headway and the Minister of Agriculture, in 1960, won a blueprint of the project through with a 17-1 vote in 
the parliamentary Finance Committee (Pedersen 2004). The Ministry of Labour placed the 33 million euro (today's prices) project on hold, because unemployment figures were low, but the chairman of the Landowner's Committee managed to make a local MP (Liberal Party) persuade the Minister of Labour (Social Democratic Party) to release the money for the project (archive files of the Heath Society). In March 1962, the excavators started digging in the steep banks of Skjern River. The project was finished in 1968.

As expected, the land reclamation network won the Skjern River battle against the nature protection network. The land reclamation network had since the $19^{\text {th }}$ century built up a unchallenged policy image, the essence of which was that land reclamation projects were e.g. of public utility and that the projects assisted in solving problems of unemployment. In the rhetoric of the network, areas were waterlogged and dewatering was a patriotic calling. Consequently, those against the projects were considered unpatriotic. The land reclamation network was exercising structural power, making the nature protection network abstain from criticizing this policy image, despite the fact that actors in the nature protection network possessed information about the expected negative consequences of a project - information that they did not dare to make public, however (archive files of the Society for Nature Conservation). But, in the 1960s it became possible to criticize the dominant policy image, when the exogenous context changed (Marsh \& Rhodes 1992).

\section{A new policy image}

From the start of the 1960s, experts representing different actors in the nature protection network unexpectedly started to spread negative information about land reclamation projects in general, and the Skjern River project in particular, in the media. In the exogenous context, unemployment figures had fallen significantly, and they remained at a steady and historically low level from 1959 to the start of the 1970s (Figure 1).

Figure 1. Approximately here 
This development meant that the land reclamation network was caught in its own official rhetoric, according to which land reclamation projects were employment-creating schemes, and this caused the perception of reality among actors in the nature protection network to change. The exogenous change gave the nature protection network a very powerful argument in the bargaining with the government: Why implement a gigantic, employment-creating project like the Skjern River project in a period where unemployment was non-existent? By forcing the Skjern River project through the political system, it seems that the land reclamation network had become too arrogant. Here, the nature protection network perceived there was an opportunity to confront the dominant policy image, and the actors in the nature protection network confronted the actions and rhetoric of the land reclamation network in public.

Additionally, other important changes in the exogenous context supported this change in perception: 1) Developments in land reclamation techniques meant that, year for year, the projects became less and less labour intensive and, in general, the effect of land reclamation projects on employment was very small (Landbokommissionen 1966).2) The period 1957-70 was historically very prosperous for the Danish economy (Hansen 1977). But the relative importance of the role of the agricultural sector in generating export income fell significantly from 74.4 pct in 1950 to 52.2 pct in 1960 and 30.8 pct in 1970 (Hansen 2001). In the exogenous context, other factors, such as the other competing networks, administrative entities, and public opinion, did not change significantly in this period (Pedersen 2006). Ideologically, there was very broad support for land reclamation projects in the Danish Parliament when the Skjern River project was implemented, as there had always been.

However, the new, openly expressed, expert information meant that the hitherto unchallenged land reclamation projects were suddenly debated in feature articles (e.g. Jyllands-Posten 21.03.1960; 06.10.1961; 21.10.1961; Politiken 21.09.1961), journalistic articles (e.g. Politiken 27.09.1961, 28.11.1961; Ringkjøbing Amts Dagblad 30.09.1961, 04.10.1961; Vestkysten 28.11.1961; Berlingske Tidende 17.10.1961; Børsen 29.11.1961), leading articles (e.g. Vestkysten 03.10.1961; Børsen 29.11.1961), in a radio programme 
(Thamdrup 1960), and on TV (archive files of the Society for Nature Conservation). And it was not only (non-existent) employment effects which were discussed. Actors from the nature protection network dragged other negative effects into the debate (ochre pollution, fishery losses, loss of scenic beauty, loss of wildlife, etc.) - information they had possessed for years, but had not dared use until this point. The core actors in the network were the same as those there had been for years, but they changed their perception (Smith 1993; 2000) of the chances of introducing a new policy image and stopping the land reclamation era.

The nature protection network did not succeed in stopping the Skjern River project, but the new negative policy image was planted and gave the members of the network a common cause. Interaction among actors in the nature protection network was intense in this period (archive files of the Society for Nature Conservation). Meanwhile, the land reclamation network desperately tried to keep the old policy image of land reclamation projects as being of public utility alive in the media (Pedersen 2006). In other words, the advantaged tried to fight back (Baumgartner \& Jones 1993: 8). However, the land reclamation network were hindered by changes in the party system, where from the start several actors involved supported the new image.

The new policy image of polluting and unnecessary land reclamation projects could be coupled to a new line of conflict in the party system. A new left-wing party, the Socialist People's Party, won access to parliament at the election in November 1960. The party was soon ready to co-opt environmental matters and in 1961 the party questioned the Minister of Agriculture about the Skjern River project (Folketingstidende 1961/62). The proportion of parliamentary debates devoted to the environment tripled in 1960 compared with the situation in the 1950s (Figure 2) and the level was maintained in 1961 and 1962, indicating the possibility of coupling the new policy image to a new (environmental) line of conflict.

Figure 2 approximately here 
The Conservative Party proposed a general debate about land reclamation projects (Vestkysten 02.11.1961) - the government agreed and when a Nature Conservation Commission was appointed in the autumn of 1961, one of the tasks was to assess land reclamation projects what made one of the nature protection networks resources - expert knowledge about nature protection - more valued. Several of the actors from the nature protection network were represented in the commission, and the many meetings in the commission further increased the interaction and understanding of land reclamation projects among these actors. When the final report was presented in 1967 it was very critical towards land reclamation projects (Naturfredningskommissionen 1967). Here, the influence of developments in other countries may have been felt, as the late 1960s and early 1970s witnessed considerable public interest in environmental policy in Europe and North America (Weale 1992: 10). State grants for land reclamation were abolished in 1970 by a huge political majority (Folketingstidende 1969/70 C: 417) - a radical policy change, a major victory for the formerly disprivileged nature protection network, and a major loss for the land reclamation network.

After 1970 Denmark entered a period of status quo. Natural areas were no longer being converted to farmland, but, on the other hand, no farmland was being returned to nature. In 1985, the nature protection network was ready to invent a new and more radical policy - nature restoration.

\section{The invention of 'nature restoration' and the decision to restore the Skjern River}

Denmark had become a member of the EC in 1973. During the early 1980s, the EC experienced serious problems concerning the common agricultural policy when huge surplus stocks were building up and marginal farmland was required to be taken out of production (Pedersen 2004:81). In June 1985, a committee in the Danish Ministry of the Environment presented a discussion paper analysing how this negative trend in the agricultural sector could be transformed into an environmental success by e.g. recreating lakes and establishing wetlands on marginal farmlands (Pedersen 2006). 
In September 1985, three months after the Ministry of the Environment's presentation of a discussion paper, the Society for Nature Conservation invited the parliamentary Radical Liberal Party on an excursion into the Danish countryside. Inspired by Prime Minister Poul Schlüter's (Conservative Party) simultaneous launch of a plan for the 'economic restoration' of Danish society, the organization launched a new term in the Danish vocabulary, 'naturgenopretning' ('nature restoration'), signalling a change from the classic, defensive, protective policy towards a much more active policy. In sum, a new policy was started, marking a move away from the traditional appreciation of nature protection policy. After the excursion, the leader of the party asked the interest organization to develop a motion for a proposal, the new word was presented in the media by the Radical Liberal Party and a political process commenced (Refn 2001:7; Pedersen 2006). The new policy image was connectable to a very hot line of conflict in Parliament (see Figure 2 above). 'Nature restoration' soon became a catchword, being mentioned in positive terms over and over by different experts from the nature protection network. A new policy and an associated positive policy image were born. Today, the word is an integrated part of the Danish vocabulary and an analysis of (electronic) newspaper articles (1985-2006) containing the word shows, that it is almost always presented with a very positive policy image (Pedersen 2006).

Parallel with the new concept of 'nature restoration', on 15 September 1986 a seminar was held on the pollution of Ringkoebing Fjord, severely polluted by ochre, nitrogen and phosphorus from the Skjern River. The Minister of the Environment (Christian People's Party) was giving a speech and was surprisingly explicit when stating: 'The bottom is dead, the fishery and the birds are in a wretched state, the water is dirty and muddy' (Ringkjøbing Amts Dagblad 16.09.86); a critique which was given attention on national television (Danmarks Radio 1986) and in newspaper articles (Pedersen 2006).

A couple of days later a marginal land conference, inspired by the discussion paper from the ministry, was convened in Skjern and a biologist from the ministry told how a restoration of the Skjern River's meanders could save the fjord by improving the stream's oxidation and by creating 'wet meadows', which could reduce the nitrogen pollution. The 
mayor (Conservative Party) of the municipality of Skjern attended both the seminar and the conference, and it would seem that he combined the information from the two events when stating on national television in November 1986, to the indignation of most farmers, 'that the regulation of the Skjern River was a crime against the nature in the river valley', and that the meandering course of the river should potentially be restored (Pedersen 2004:79). An idea which was first presented in a nature programme on national TV a couple of weeks earlier. In January 1987, the Social Democratic Party, which was part of what was termed the 'alternative green majority' in parliament opposing the Liberal-Conservative minority government, proposed restoration of the meanders in the river, with the purpose of reducing pollution and improving recreational value. The proposal was passed with a sizeable majority in May 1987, and a committee was appointed to draw up plans for the project. In 1999, the excavators were back in the Skjern River valley. However, this time they were not straightening the river but restoring its meanders instead. The farmland was acquired by the state by purchase or exchange with the farmers. A handful of farmers were expropriated. When the project was finished, more than 2,000 hectares of the dewatered 4,000 hectares were restored. Ironically, the cost was the same as that for straightening the river in the first place: 33 million euro (2004 prices) (Pedersen 2004).

After the decision in the Danish parliament to restore Skjern River, the first milestone for a new restoration policy, general acts regarding nature restoration have been enacted and 18,000 hectares have been purchased (1989-2004) by the state and restored (Skov- og Naturstyrelsen 2005). During these years, in general, actors of the nature protection network have experienced very frequent interaction within councils, committees, etc. regarding nature restoration, which has strengthened the network further. But, what happened to the strong land reclamation network?

The local farmers/landowners were fiercely opposed to handing over farmland to a Skjern River restoration project, e.g. claiming that the project would ruin them, that the project was an insult towards the hard work carried out by their ancestors in straightening the river, or that the project was developed by Copenhageners knowing nothing about conditions 
in Western Jutland. The farmers' local organization attempted to activate the former strong policy community by asking for the help of the national agricultural organization, but did not succeed (Pedersen 2004). In the working group responsible for preparation of a particular Skjern River restoration project, the local farmers possessed two seats and fought against a comprehensive project. However, they constituted a minority in the group, which was dominated by pro-restoration interests (ibid).

The main problem for the land reclamation network was that it was severely weakened compared with the situation in the 1950s, when the Skjern River straightening project was planned. The former ally, the Ministry of Agriculture, was not involved in the decision-making process. The national agricultural organizations were not particularly helpful either: they were aware that there was a problem regarding pollution with nutritive salts; they were aware that Denmark, as a member of EC, needed to take marginal farmland out of production, and the farmland of the Skjern River valley was marginal like most farmland in drained river valleys; environmental problems were high on the political agenda; and, meanwhile, agricultural interests were fighting against a potentially more burdensome Action Plan for the Aquatic Environment (Pedersen 2004:80-81). Therefore, the agricultural organizations held a low profile. Furthermore, actors had disappeared from the network (see also Baumgartner \& Jones 1993:8). The once powerful Land Reclamation Board was abolished in 1970 and, later, the Heath Society was deprived of its state grants (Hansen 2003:50), leading the company to switch networks. The company changed perception of reality (constraints and opportunities) and the engineers now turned attention to nature restoration projects instead of land reclamation projects as a source of income (Pedersen 2004:81) - a perception which diverged markedly from the general appreciative system of the land reclamation network. Institutionalization had weakened in the network, there was almost no public support for the old policy image, and meetings became fewer due to the abolishment of the Land Reclamation Board in 1970. As a result of the policy image of the nature protection network, the land reclamation network was now subordinate to the structural power of the nature protection network. 
Furthermore, the nature protection network had strengthened over the years. The Ministry of the Environment (created in 1971), a result of the focus on environmental matters in the 1960s, was a new powerful actor in the network and, moreover, some of the ministerial employees in the agency responsible for nature restoration projects were also members of the executive committee of the Danish Ornithological Society (Pedersen \& Geckler 1987: 114) another member of the nature protection network.

Additionally, the Society for Nature Conservation appointed a new president in 1984, and the organization took on a more aggressive and media-oriented policy style. At the time of the introduction of the term 'nature restoration', the organization had an impressive number of members: 245,000 (Svold 1989:28,44). One out of twenty Danes was a member of the organization.

Two other old members of the network, the Danish Angling Association and the Danish Outdoor Council, became more active as well. The Danish Outdoor Council, the Society for Nature Conservation and the Danish Ornithological Society actually set up an unofficial contact group regarding nature protection policy in 1978, which was used to come in contact with all the parliamentary parties (Ferdinand 1993: 169). Furthermore, during the 1980s and 1990s, the environmental organizations became more involved in the political decision-making processes, including those surrounding the Skjern River (archive files Ministry of the Environment) - they wanted the meanders back.

The network exercised considerable influence on both the decision to restore the Skjern River and on the actual implementation of the project (Pedersen 2006) - initially by inventing the Danish term for 'nature restoration'. Later, e.g. at the meeting where the Minister of Environment stated 'the bottom of the fjord is dead....' (see above). Here a very skilled lobbyist from the Danish Angling Association had foreseen that important statements might come from the minister at the meeting and, therefore, had invited a couple of TV journalists (Interview Børge Christensen 2004). They were not disappointed and the minister's harsh statement was broadcast several times on national TV, putting the river on the media agenda. 
Furthermore, a local MP of the Social Democratic Party attended the meeting and, hearing the minister's statement, started to discuss a potential Skjern River restoration project with another Social Democratic MP, who was also president of the Danish Outdoor Council and, in addition, a friend to the lobbyist from the Danish Angling Association (Interview Børge Christensen 2004; Interview Henning Nielsen 2004). The Danish Outdoor Council is an umbrella organization - one of the members being the Danish Angling Association. The two Social Democrats and the anglers' lobbyist became the driving forces behind the formulation of the parliamentary proposal.

Initially, the main aim of the project was to diminish the discharge of nutritive salts to the fjord, but during the implementation phase, the nature protection network managed to make the focus shift towards creating a bigger and a more spectacular nature restoration project instead of 'just' focusing on nutrients (archive files Ministry of the Environment) - a change which ornithologists, conservationists, anglers, and outdoor enthusiasts, alike, could not be dissatisfied with, and therefore a magnificent victory for the nature protection network.

The period in the mid-1980s, where actors of the nature protection network introduced 'nature restoration' with a very positive policy image, and pushed a Skjern River restoration proposal forward, was a period where important changes in the exogenous context were observable. Exogenous changes which changed the perception of reality, and the bargaining power, of the actors in the nature protection network.

There was some new information about nitrogen pollution and the positive effect of river meanders, and a new important Ministry of the Environment had been born. Economic progress had continued, unemployment was low, and the relative importance of the agricultural sector had continued to fall. But no new networks had emerged. However, it seems that especially two contextual factors were important for the new perception of the situation which diverged markedly from the former appreciative system of the network based on (passive) nature protection and not (active) nature restoration. 
Ideologically, during the years 1982-1988 an extraordinary situation prevailed in Danish parliament. The centre-right minority government faced a so-called 'alternative green majority coalition', which consisted of the left-wing parties, the Social Democrats and the Radical Liberals. On a number of occasions, this majority forced the minority government to adopt certain environmental policies which it disliked. The formal proposal to restore the Skjern River came, as described, from the Social Democratic Party (inspired by actors in the nature protection network), and was supported by the other members of the 'alternative green majority coalition' - an ideological factor which also improved the bargaining power of the nature protection network.

Furthermore, the weight given by the public to environmental matters peaked in 1987, the time when the Skjern River proposal was passed and a nature restoration policy proposed (see Table 1).

Table 1 approximately here

This also represented a development that supported actors of the nature protection network, and political parties with a 'green' profile.

The party system's very hot line of conflict regarding environmental matters in fact created a policy window that was wide open (Kingdon 1984; Baumgartner \& Jones 1993: 2829), thereby preparing the ground for a whole new policy - one which diverged markedly from the prevailing nature protection policy and which could easily be connected to a positive image, but at the same time one which immediately was supported by all actors in the nature protection network. If an environmental line of conflict had not been present in the party system, it would seem that radical policy changes would have been an unlikely outcome, because the whole Skjern River debate was centered on the pollution reduction effects.

\section{Conclusion}


The comparison of the 33 million euro decision in 1960 to straighten Skjern River and the 33 million euro decision in 1987 to restore the river demonstrates a u-turn in Danish rural policy regarding land-use in the wider countryside. When the river was straightened, a strong land reclamation policy community was creating power relations which privileged the actors of the policy community and disprivileged a weak nature protection network. But, from the mid1980s the nature protection network had turned the situation upside down, and was here privileged by nature restoration policies.

Radical changes in the exogenous context of the nature protection network (Marsh \& Rhodes 1992), primarily the minimal unemployment during the 1960s, changed the actors' perception of reality (Smith 1993; Smith 2000) and their bargaining power (Blom-Hansen 1997) so, after the Skjern River decision, they dared to build a new negative policy image around land reclamation policy in general, and they dared to criticize the Skjern River 'jobcreation' project in particular. The new policy image had an integrating effect on the nature protection network, and could be coupled, not to a new policy venue as predicted by Baumgartner \& Jones (1993), but to a new line of conflict in the party system (see GreenPedersen 2007) regarding environmental matters which politicized the issue. The result was a radical policy change when a stop was put to land reclamation policy in 1970.

From the mid-1980s, changes in the exogenous context (especially 'ideological changes' and 'changes in public opinion') opened a policy window (Kingdon 1984) and, once again, changed the actors' perception of reality and their bargaining power, and a whole new nature restoration policy was proposed. A new positive policy image surrounding nature restoration was promoted, making the nature protection network more institutionalized and integrated, while having a disintegrating effect on the land reclamation network, especially by making one of the main actors of the land reclamation network swap networks. Again, the new policy with the positive image was connected to a hot line of conflict. Environmental matters ranked very high on the political agenda 1985-88. A new nature restoration policy was the result, farmland now being converted to 'wild nature', and the Skjern River project was the first restoration project in large scale. 
The findings demonstrate the benefit of adding elements from Baumgartner \& Jones' (1993) model to policy networks. It is suggested that changes in the exogenous context of a policy network can result in network changes by altering central actors' perception of reality and bargaining power, which, in turn, can make these actors build up and communicate a new policy image or strengthen an existing image. A new policy image can improve the networks institutionalization and integration, and furthermore may add new strong actors to the network (Baumgartner \& Jones 1993: 8). These represent factors which can explain policy network change; a finding which, in addition to explaining policy network change, adds content to an underdeveloped area of research - the institutionalization dimension of policy networks (see Atkinson \& Coleman 1992). Furthermore, if the new policy image is connectable to a line of conflict in the party system, this makes explanation of policy change possible.

Normally, it will be possible to identify two (or more) conflicting policy networks also in other countries, when analyzing land reclamation and nature restoration policies (e.g. in the UK, Germany and the Netherlands). It is therefore suggested that the framework might be beneficial when analysing these policies in other countries where 'line of conflict' seems to be more important than 'policy venue'. Additionally, the framework might be useful when analysing other issue areas.

\section{References}

Andersen, J.G., 2003, 'Vælgernes nye politiske dagsorden', in J.G. Andersen \& O.Borre (eds.), Politisk forandring: Vardipolitik og nye skillelinjer ved folketingsvalget 2001, Århus: Systime.

Archive files of the Heath Society.

Archive files of the Land Reclamation Board.

Archive files of the Ministry of Environment.

Archive files of the Society for Nature Conservation.

Atkinson, M.M. \& W.D. Coleman, 1992, 'Policy Networks, Policy Communities and the Problem of Governance', Governance, 5, pp.154-80. 
Baumgartner, F.R. \& B.D. Jones, 1993, Agendas and Instability in American Politics,

Chicago \& London: The University of Chicago Press.

Berlingske Tidende (Danish newspaper).

Blackbourn, D., 2006, The Conquest of Nature: Water, Landscape, and the Making of Modern Germany, New York: W.W. Norton \& co.

Blom-Hansen, J., 1997, 'A ”New Institutional” Perspective on Policy Networks', Public Administration, 75, pp.669-93.

Bulkeley, H., 2000, "Discourse coalitions and the Australian climate change policy network", Environment and Planning C: Government and Policy, 18, pp.727-48.

Børsen (Danish newspaper)

Danmarks Radio, 1986, Det Derude, 04.09.1986.

Danmarks Statistik, 1996, 'Arbejdsløshedsserier 1910-1995', Statistiske Efterretninger, 28, pp.1-16.

Daugbjerg, C., 1998, Policy Networks under Pressure: Pollution Control, Policy Reforms, and the Power of Farmers, Aldershot: Ashgate Publishing.

Daugbjerg, C. \& A.B. Pedersen, 2004, 'New Policy Ideas and Old Policy Networks: Implementing Green Taxation in Scandinavia', Journal of Public Policy, 24, pp.21949.

Dowding, K., 1995, 'Model or Metaphor? A Critical Review of the Policy Network Approach', Political Studies, 43, pp.136-58.

Dowding, K., 2001, 'There Must Be End to Confusion: Policy Networks, Intellectual Fatigue, and the Need for Political Science Methods Courses in British Universities', Political Studies, 49, pp.89-105.

Ferdinand, L., 1993, Natur, Fugle og Fuglefolk: Erindringer om en brydningstid for fugle og naturbevarelse, Forlaget Rhodos.

Flyvbjerg, B., 2003 (1991), Rationalitet og magt: Det konkretes videnskab, Akademisk Forlag.

Folketingstidende (Danish parliamentary journal) 
Geckler, R., 1982, Hvad indad tabes - Hedeselskabets virksomhed, magt og position, København: Gyldendal.

Green-Pedersen, C., 2006, 'Long-term Changes in Danish Party Politics', Scandinavian Political Studies, 29, 221-37.

Green-Pedersen, C., 2007, 'The Conflict of Conflicts in Comparative Perspective: Euthanasia as a Political Issue in Denmark, Belgium, and the Netherlands', Comparative Politics, 39, pp.273-91.

Hansen, H.O., 2001, Landbrug $i$ et moderne samfund. Landbrugets placering, udvikling og omverden i et velfardssamfund, København: Handelshøjskolens Forlag.

Hansen, K., 2003, Der er et yndigt land. En fattig natur i et rigt samfund-status over Danmarks natur, Copenhagen: Gads Forlag.

Hansen, S.A., 1977, Økonomisk vakst i Danmark, København: Københavns Universitet.

Hertz, M., 1996, Et ministerium finder sin form: Landbrugsministeriet 1896-1923, GEC GAD.

Interview Børge Christensen, 2004, lobbyist, Danish Anglers Federation, personal communication.

Interview Henning Nielsen, 2004, former MP, Social Democratic Party, personal communication.

Jordan, G., 1998, 'Indirect Causes and Effects in Policy Change: The Brent Spar Case', Public Administration, 76, pp.713-40.

Jyllands-Posten (Danish newspaper).

Kingdon, J., 1984, Agendas, Alternatives, and Public Policies, Harper-Collins.

Kraks Blaa Bog (Danish reference book)

Landbokommissionen, 1966, Betcenkning afgivet af Landbokommissionen af 1960. Fjerde del om landvinding m.m. (betænkning nr. 410), København.

Larsen, K. \& S.Olsen, 1947, 'Okkerkvælning af Fisk i Tim Aa. Udledning fra Brunkulsleje som Aarsag til Katastroferne i Nørre Esp Ørreddambrug 1941-1947’ p.325 in Beretning til Ministeriet for Landbrug og Fiskeri fra Den Danske Biologiske Station vol.50. 
Maass, A., 1951, Muddy Waters: The Army Engineers and the Nations Rivers, Cambridge, Massachusetts: Harvard University Press.

Madsen, F.K., 1979, Naturfredningssagens historie i Danmark, Odense: Odense Universitet.

Marsh, D., 1998, 'The utility and future of policy network analysis' in D.Marsh (ed.), Comparing Policy Networks, Buckingham \& Philadelphia: Open University Press, pp.185-97.

Marsh, D. \& R.A.W. Rhodes (eds.), 1992, Policy Networks in British Government, Oxford: Clarendon Press.

Marsh, D. \& M.Smith, 2000, 'Understanding Policy Networks: Towards a Dialectical Approach', Political Studies, 48, pp.4-21.

Naturfredningskommissionen, 1967, Betcenkning om naturfredning II.

Pedersen, A.B., 2004, 'Først den ene vej og så den anden vej: De politiske beslutningsprocesser vedrørende udretning og genslyngning af Skjern Å’, Politica, 36, pp.71-87.

Pedersen, A.B., 2006, Fra landvindingspolitik til naturgenopretningspolitik-policy-netvarks magt og forandring, Aarhus: Politica (Ph.D.-thesis).

Pedersen, J.F. \& R.Geckler, 1987, 'Græsrødder og embedsmænd' in R.Geckler \& J.G. Christensen (eds.), På ministerens vegne, København: Gyldendal.

Politiken (Danish newspaper)

Refn, J., 2001, '90 år i naturens tjeneste', Natur og miljф, no.2, pp.4-9.

Richardson, J., 2000, 'Government, Interest Groups, and Policy Change', Political Studies, 48, 1006-1025.

Rigsdagstidende (Danish parliamentary journal)

Ringkjøbing Amts Dagblad (Danish newspaper)

Skov- og Naturstyrelsen, 2005, arealerhvervelser.

Smith, A., 2000, 'Policy Networks and advocacy coalitions: explaining policy change and stability in UK industrial pollution policy', Environment and Planning C: Government and Policy, 18, pp.95-114. 
Smith, M.J., 1990, The Politics of Agricultural Support in Britain: The Development of the Agricultural Policy Community, Aldershot: Dartmouth.

Smith, M.J., 1993, Pressure, Power, and Policy, New York \& London: Harvester Wheatsheaf.

Svold, C., 1989, Danmarks Naturfredningsforening: Fra paen forening til aggressiv miljøorganisation, Århus: PLS Consult.

Thamdrup, H.M., 1960, 'Hedeselskabet og det danske landskab', Hedeselskabets Tidsskrift, 81, pp.95-102.

Toke, D. \& D.Marsh, 2003, 'Policy Networks and the GM Crops Issue: Assessing the Utility of a Dialectical Model of Policy Networks', Public Administration, 81, pp.229-251.

Vestkysten (Danish newspaper)

Weale, A., 1992, The new politics of pollution, Manchester \& New York: Manchester University Press.

Yin, Robert K., 1994, Case Study Research - Design and Methods, Thousand Oaks: Sage Publications. 


\section{Acknowledgement}

For helpful comments on earlier versions of the paper I am grateful to my colleagues at the National Environmental Research Institute, Department of Policy Analysis, and at the Department of Political Science, University of Aarhus. Furthermore, Carey Smith has done an excellent job in improving my English. An earlier version of the paper was presented in working group 29, 'Changing Frameworks of Agricultural and Rural Policy', at the XIth World Congress of Rural Sociology, Trondheim, Norway, July 25-30 2004. I thank the participants for valuable comments, and the organizers for picking my paper with reference to getting some of the papers published in a special issue of Public Administration. I am also deeply indebted to four anonymous reviewers and the Editor and Assisting Editor of Public Administration.

Figure 1. Unemployment among unemployment insured, 1931-1977

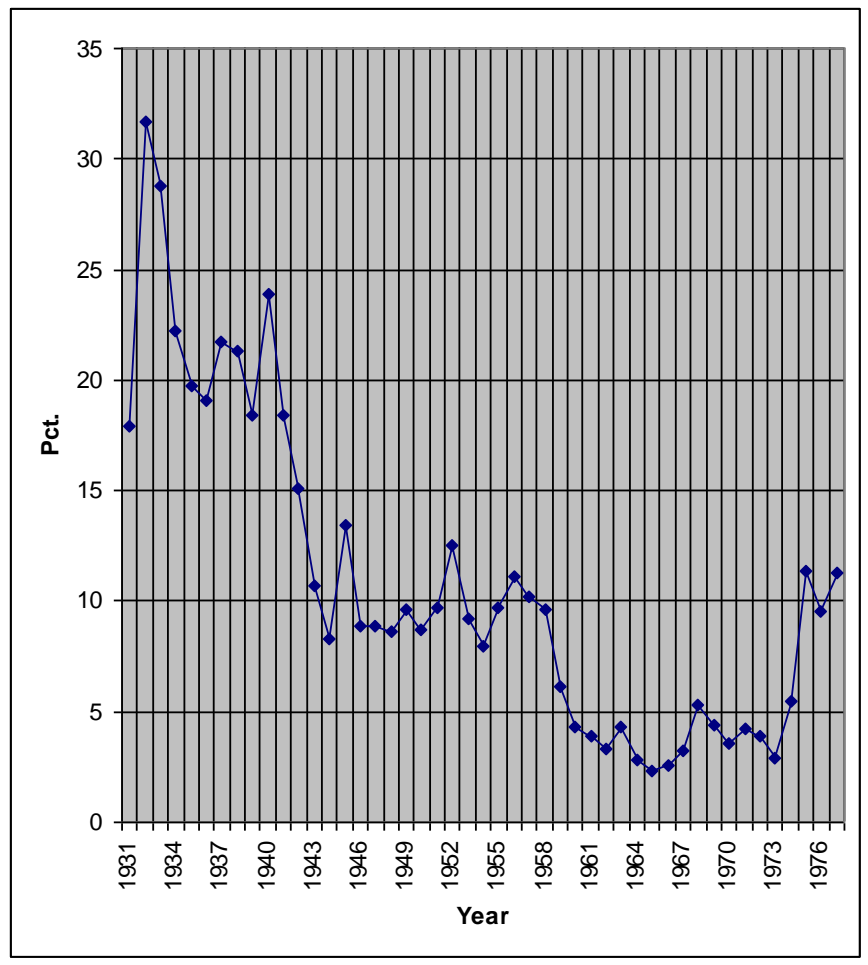

Source: Danmarks Statistik 1996 
Figure 2. Proportion of parliamentary debates devoted to the environment, 1953-2002

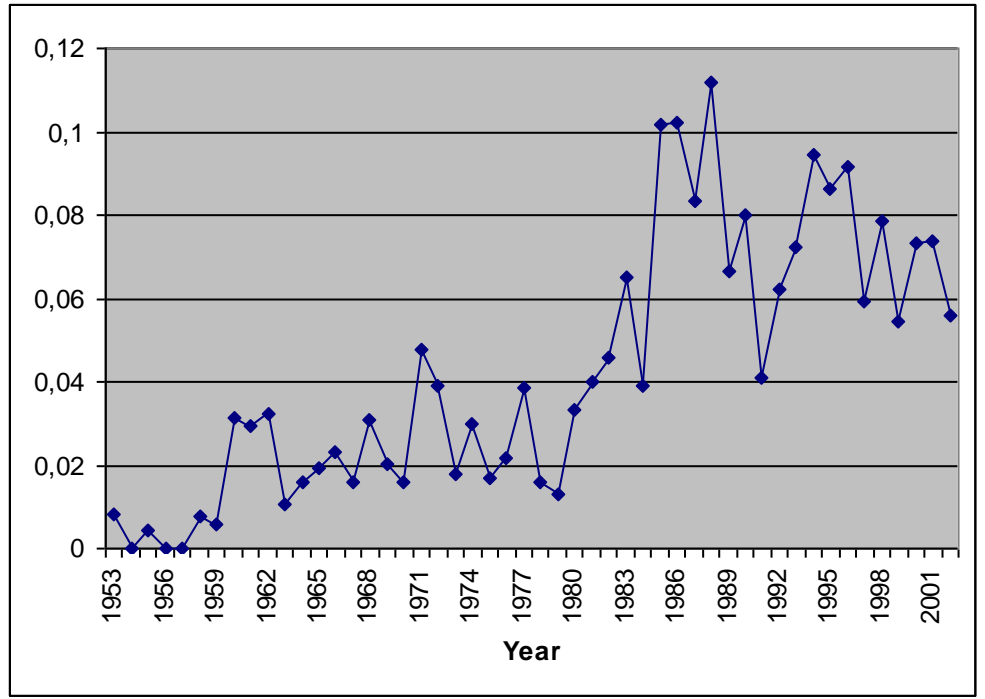

Source: Green-Pedersen 2006

Table 1. Percentage of voters giving highest priority to environmental matters on the political agenda. Parliamentary elections 1971-2001

\begin{tabular}{|c|c|c|c|c|c|c|c|c|c|c|c|c|c|}
\hline Year & 1971 & 1973 & 1975 & 1977 & 1979 & 1981 & 1984 & 1987 & 1988 & 1990 & 1994 & 1998 & 2001 \\
\hline Pct & 8 & 4 & 1 & 3 & 6 & 2 & 3 & 15 & 9 & 10 & 8 & 9 & 4 \\
\hline
\end{tabular}

Question: What problems, which politicians should attend to, do you think are the most important today?

On average, respondents named 2.4 issues in 1998, 2.5 in 2001 and approx. 2 in the 1970s.

Source: Andersen (2003: 138) 